\title{
Study on owlet moths (Noctuidae: Lepidoptera) from district Khairpur Mir's Pakistan
}

\author{
Paras Soomro', Abdul Manan Shaikh ${ }^{1}$, Waheed Ali Panhwar ${ }^{1 *}$,
} Khadim Hussain Memon ${ }^{1}$, Safdar Ali Ujjan ${ }^{1}$, Javed Ahmed Ujjan ${ }^{1}$, Zaib Un Nisa Memon ${ }^{1}$, Majeeda Ruk ${ }^{1}$ and Shabana Mangi ${ }^{1}$

1. Department of Zoology, Shah Abdul Latif University Khairpur Mirs Sindh, Pakistan

*Corresponding author's email: waheed.panhwar@salu.edu.pk

Citation

Paras Soomro, Abdul Manan Shaikh, Waheed Ali Panhwar, Khadim Hussain Memon, Safdar Ali Ujjan, Javed Ahmed Ujjan, Zaib Un Nisa Memon, Majeeda Ruk and Shabana Mangi. Study on owlet moths (Noctuidae: Lepidoptera) from district Khairpur Mir's Pakistan. Pure and Applied Biology. Vol. 10, Issue 4, pp1380-1387. http://dx.doi.org/10.19045/bspab.2021.100143

\begin{tabular}{|c|c|c|c|}
\hline Received: $25 / 01 / 2021$ & Revised: $26 / 03 / 2021$ & Accepted: $12 / 04 / 2021$ & Online First: $22 / 04 / 2021$ \\
\hline
\end{tabular}

\section{Abstract}

Noctuidae or owlet moths are group of robust moths. The name of this family is taken from the way that night species have eyes, with reflect light with and an orange gleam. Most species are dim to cocoa in color frequently with dim and light spots on the forewings. They are nocturnal and are normally attracted to lights those larvae of Noctuidae have tufts of short abounds and might be brilliantly colored. Most are foliage feeders and the insatiable hungers of few species have turned them to serious pest of wide range of crops and thus they are known as armyworms and cutworms. Extensive surveys were carried out to collect Noctuidae fauna of district Khairpur Mirs. A total of 221 specimens were captured and were identified into 11 genera and 15 species of Noctuidae i-e: Mythimna unipuncta, (Haworth, 1809), Mythimna impura (Hübner, 1808), Heliothis adaucta Butler, 1878, Heliothis peltigera (Denis \& Schiffermüller, 1775), Agrotis ipsilon (Hufnagel, 1766), Agrotis exclamationis (Linnaeus, 1758), Meterana pansicolor (Howes, 1912), Meterana alcyone (Hudson, 1898), Spodoptera litura (Fabricius, 1775), Grammodes stolida (Fabricius, 1775), Graphania pagaia (Hudson, 1909), Helicoverpa armigera (Hübner, 1808), Heliothis armigera (Hübner, 1808) Dipaustica epiastra (Meyrick, 1911) and Dysgonia algira, Linnaeus in 1767. Beside this, description for species along with digital images were also provided for easily identification of species. Present study is an initiative step towards the biodiversity of Noctuidae fauna of district Khairpur Mir's.

Keywords: Biodiversity; Lepidoptera; Noctuidae; Species; Taxonomy

\section{Introduction}

Moths and butterflies belongs to order Lepidoptera are phytophagous insects and are considered as prime insects in the world [1]. There are about $(15,5000)$ well known species found worldwide [2, 3]. Mostly, Lepidopteran are distinctive group of insects in ecosystem, consuming plants, larvae as well as adult feed on nectar [4]. They act as herbivorous, predators and important pollinators and additionally being a standout among severe harming to agricultural crops [5]. Nearly six thousand species of Lepidoptera are regarded as financial importance [6].

Around one fourth of these have a place with the Noctuidae. In spite of the fact that the countless species can be assigned as pests [7], named the pests clade, many more are taken over the entire family Noctuidae 
in more than five hundred (500) genera. These caterpillars of numerous noctuid genera cause commercial loss yearly [8]. Also, these grown up of a few genera harm crops having fruit by perforating the stains to slurp juices $[9,10]$.

Taxonomic isolation of Lepidoptera has been on the premise of morphological characters, for example, labial palpi, reception apparatus structure and wing venation etc. as of the late significance of outer genital morphology the lepidopteran scientific categorization and phylogeny has been well recognized [11]. A few examinations have been made on the general external morphology of various lepidopteran groups such as systematic importance of the male genitalia in micro Lepidoptera [12]. The morphological significance of juxta in the male genitalia of Lepidoptera and considered loss of juxta to check out high level of genitalia specialization piece [13]. Significance of genitalia at the particular level and communicated the view that within reversion examines, more prominent reliance ought to be set on the inner genitalia [14].

Noctuidae or owlet moths are group of robust assembled moths that incorporates more than 35,000 known species out of 100,000 species in more than 42,00 genera they constitute the biggest family in the Lepidoptera, with 1,450 species found in Europe [15]. The name of this family is gotten from the way that night spices have eyes, with reflect light with and an orange gleam. This is biggest family comprised of species with a various scope of attribute and in that capacity a general interpretation is too difficult. They are little to a substantial moth with a wing span extending in size from 10 to 170 millimetres relying upon the species. Most species are dim to cocoa in color frequently with dim and light spots on the forewings. Most of species are nocturnal and are normally attracted to lights those larvae of Noctuidae have tufts of short abounds and night be brilliantly colored. Most are foliage feeders and the insatiable hungers of few species have turned them to serious pest of wide range of crops and thus they are known as armyworms and cutworms [16]. The distribution of Noctuidae from Khyber Pakhtunkhwa and the noctuidae are severe pests of agricultural crops. Beside this, they reported first presence of $P$. xyllostella from KPK Pakistan [17].

In any case, numerous species of Noctuidae have minor organs in their ear that react to bat echolocation calls, sending their wing muscles into fit and bringing about the moths to dash inconsistently. This guides the moths in side stepping the bats $[18,19]$. As Noctuidae are an important agricultural point view, hence keeping in view importance, study is designed to conduct on the noctuid moths of district Khairpur.

\section{Materials and Methods}

The study was conducted from various areas of district Khairpur. Khairpur district is located at the south of Indus river with latitude $27^{\circ} 32^{\prime} \mathrm{N}$ and longitude $68^{\circ} 46^{\prime} \mathrm{E}$. Moths were captured from light traps and by using traditional insect net from the numerous zones of district Khairpur. Moths were killed in insect killing jars comprising potassium cyanide $(\mathrm{KCN})$. The insects were pinned on thorax through insects' pins. The moths were properly labelled with information place of collection, collection date, collector name and name of the host plant. Identification of moths was carried out with the help of literature and dissection of genitalia [11, 14]. The scheme for extraction of genitalia of moths given by (Eyer 1926) was adopted. Firstly, abdominal part of moths was separated and kept discretely in $\mathrm{KOH}$ (Potassium hydroxide) overnight to remove extra muscles severely sclerotized samples were boiled for 10-15 min. and then wash away in water for 5 minutes [9]. The important diagnosis characters were noted and photographs were captured with the help of "BD-45T1 trinocular Stereo Microscope".

\section{Results \\ Systematics position}

Kingdom: Animalia 
Phylum: Arthropoda

Class: Insecta

Order: Lepidoptera

Superfamily: Nocutuidea

Family: Noctuidae

\section{Family Noctuidae}

Noctuidae is second largest family of moths in order Lepidoptera and have great economic importance. Adult moths vary in size from small to medium, having 10 to 40 $\mathrm{mm}$ wing span. Head of noctuids protrude beyond the eyes making "snout" shape. Labial palps extended and mouth parts of most of species are enlarged.

\section{Pest status}

Many species of Noctuidae are polyphagous in nature such as Helicoverpa armigera a widely distributed species. This species deposits it eggs in tender leaves where they hatch in 03 to 07 days. The hatched larvae feed on fresh leaves as scrapers and as they grow thus feed chew leaves and causing severe agricultural loss to the crop. Agrotis ipsilon is also considered as persistent pest for the green lands and trees worldwide. Initially their larvae feed on foliage later on the shoots of grass and often feeding on surface of stems.

Noctuidae species

During present study 221 moth specimen were captured then were identified into 15 species of Noctuidae (Table 1 \& Fig. 1).

Table 1. Showing Noctuidae species

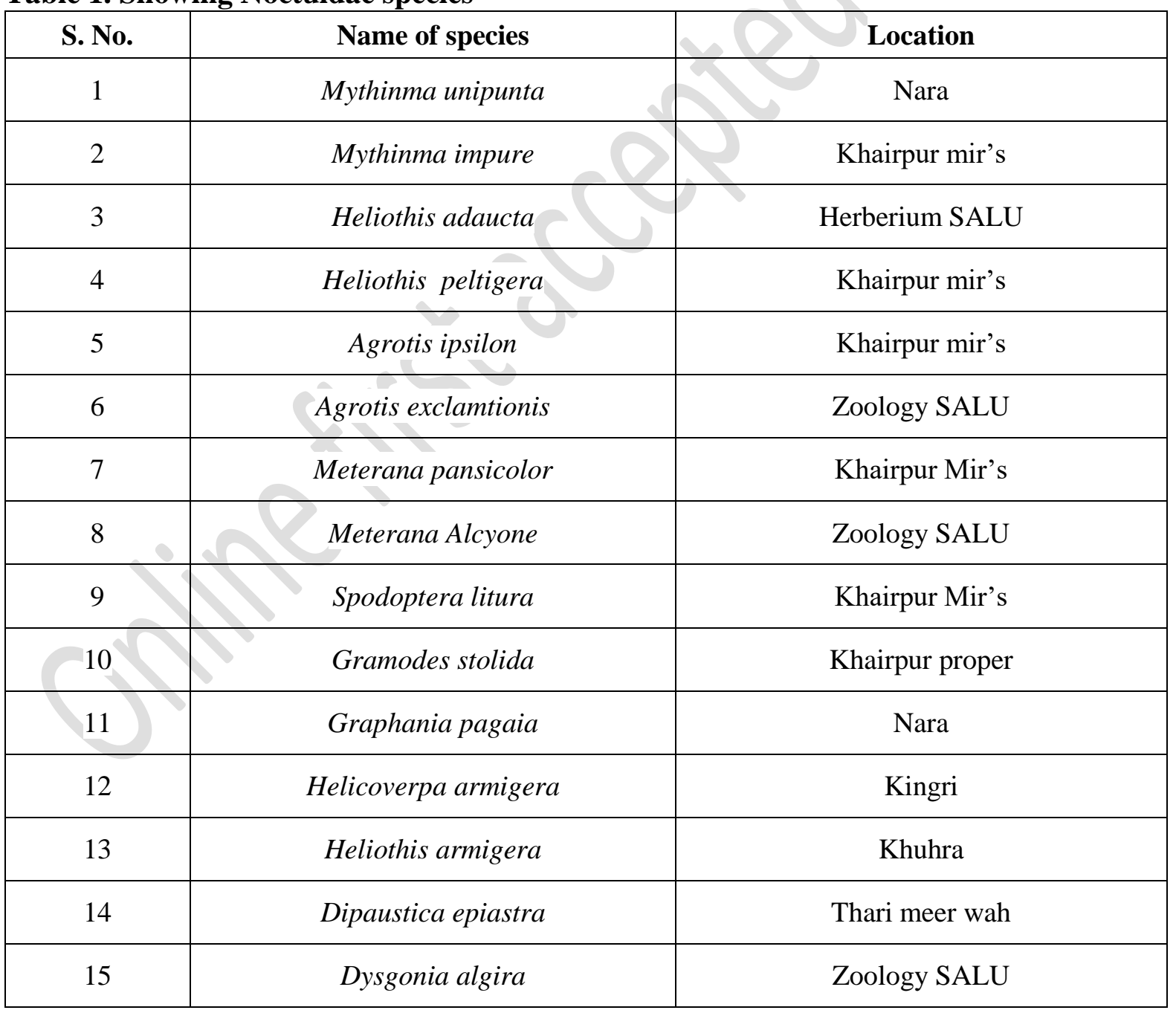




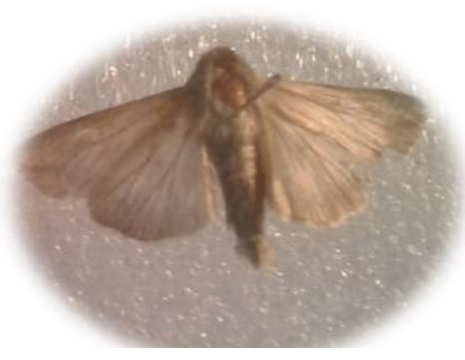

Mvthinmo uninunto

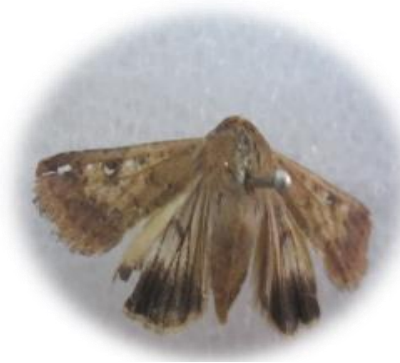

Heliothis peltigera

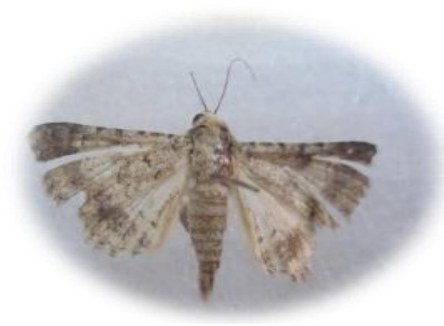

Meterana pansicolor

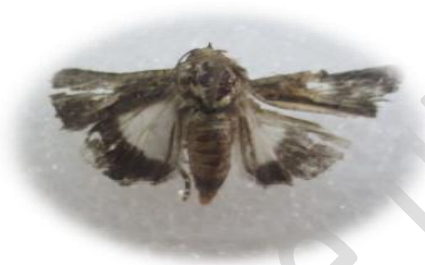

Grammodes stolida

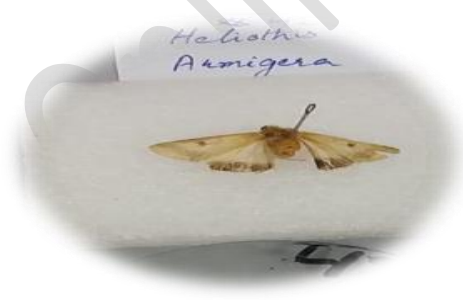

Heliothis armigera

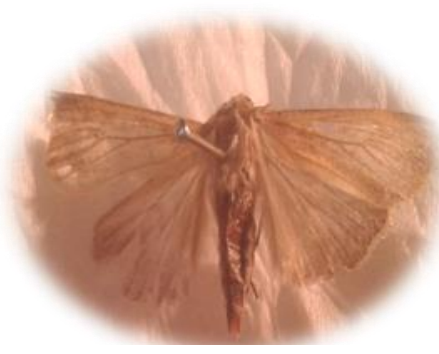

Mvthimna imnura

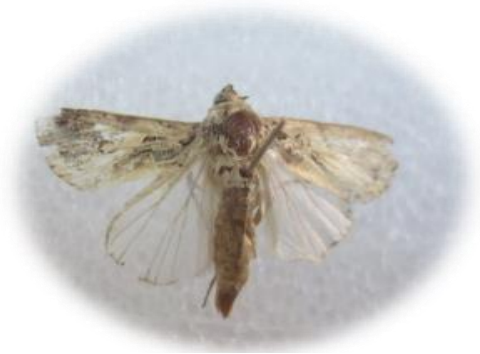

Agrotis ipsilon

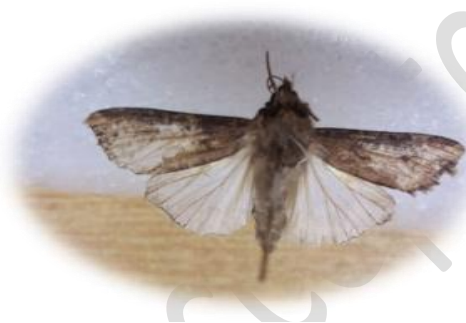

Meterana alcyone

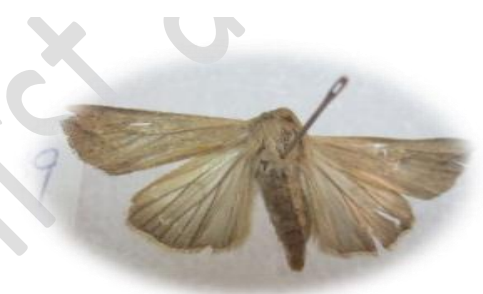

Graphania pagaia

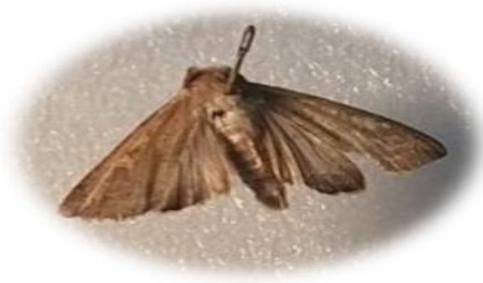

Divaustica eviastra

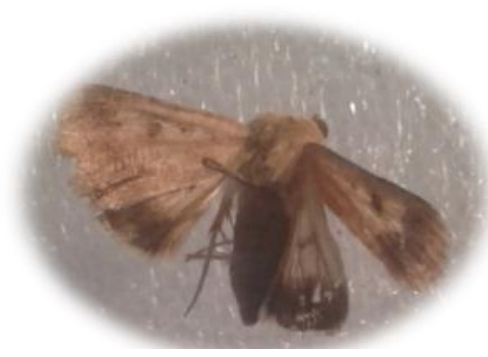

Helinthis adaucta

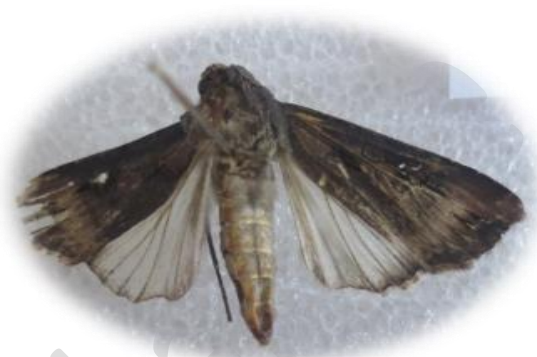

Agrotis exclamationis

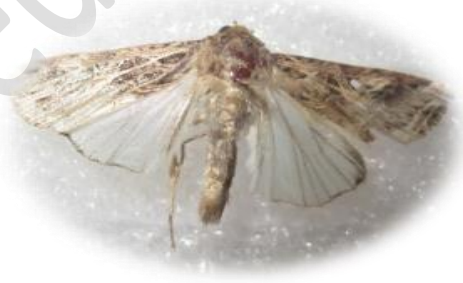

Spodoptera litura

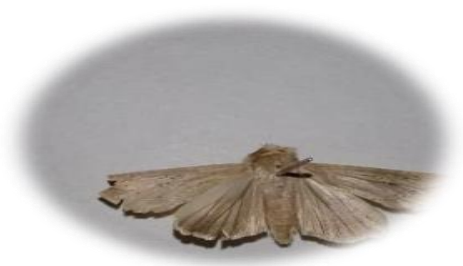

Helicoverpa armigera

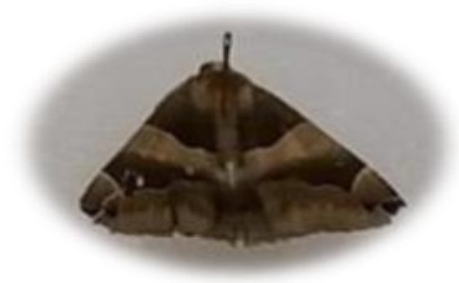

Dvsgonia algira

Fig. 1. Showing the owlet moths of Khairpur Mirs Sindh Pakistan

Description of Noctuidae species (Fig. 1) Mythimna unipuncta, (Haworth, 1809) Diagnosis

Wing span of adult is about 04 centimeters in length. Anterior part of frontal wing with blackish dots on its edge and pointed at its apex region. Numerous whitish dots present on center and darker area. Many gray tints available on hind wings. The genitalia of 
this species is elongated and truncate at its apical margins.

\section{Material examined}

Pakistan, $\$ \hat{\sigma}$ Sindh Province Khairpur Mir's, 1.vii.2018.

\section{Mythimna impura (Hübner, 1808)}

\section{Diagnosis}

The frontal wings ochreous having tinge on veins particularly median vein. Besides having brown streak that is seen from its inter space. Cells of wing veins with blackish clot at low angle. Hind wings with dull greyish colour. The genitalia are relatively long but narrowed at apex.

\section{Material examined}

Sindh Khairpur Mir's several specimens, 26.vi.2017-2018.

\section{Heliothis adaucta Butler, 1878 \\ Diagnosis}

The shoulder-striped clover noctuid moth species. The wing span is $30-36 \mathrm{~mm}$. Adults have dots on the wings. Hind wings have blackish lunar shape structure. Genitalia less or more conical with pointed hairs.

\section{Material examined}

Sindh Khairpur Mir's several specimens, 26.vi.2017-2018.

\section{Heliothis peltigera}

(Denis \& Schiffermüller, 1775)

\section{Diagnosis}

The Greek epithet "Heliothis" means "scorched by the sun", while the Latin species name peltigera means wearing a small shield, with reference to the reniform marking on the forewings. Forewings are usually greyish in color. The genitalia broaden at its base and cylindrical at its posterior region.

Material examined: Sindh Khairpur Mir's several specimens 10.x.2018.

Agrotis ipsilon (Hufnagel, 1766)

Diagnosis

Wing span is about $42-56 \mathrm{~mm}$ of adults. Frontal wings are darker brown and irregular bands are available on distal part. Hind wings are white to grey having coloured veins. Genitalia slightly asymmetrical, right valve of the genitalia is slightly narrower.

\section{Material examined}

Sindh Khairpur Mir's several specimen 9.x.2018.

Agrotis exclamationis (Linnaeus, 1758)

Diagnosis. Ground colour ranges from pale brown to blackish; oval. Kidney and dart marks prominent. Genitalia nearly straight. Genitalia straight with hook shaped structure at its anterior region.

\section{Material examined}

Sindh Khairpur Mir's several specimens 5.vii.2018

\section{Meterana pansicolor (Howes, 1912)}

\section{Diagnosis}

The head of this species protrude beyond. Thorax rufous with slightly tinges Filiform antennae. Minute numerous dots available on abdomen, crests strong, particularly at its posterior part. Frontal wings rufous with several markings. Later wings having brownish patches and color. Genitalia short, with cranial crest membernous.

\section{Material examined}

Sindh Khairpur Mir's several specimens 03.vii. 2018

\section{Meterana alcyone (Hudson, 1898) \\ Diagnosis}

Head and thorax grey and with sparse black scale. Collar darker as compared to other species of this genus. Wings light greybrown, outer part slightly darker. Hind wings are white in color. Genitalia relatively short, unilobed with distinct margins when observed.

\section{Material examined}

Sindh Khairpur Mir's several specimens 5.ix.2018

Spodoptera litura (Fabricius, 1775)

\section{Diagnosis}

Forewing length is $14-17 \mathrm{~mm}$. While female forewing length is slightly larger and measures $15-18 \mathrm{~mm}$. The orbicular spot on the forewing is also more pronounced. Generally, slicky brown in coloration. Genitalia very unique in this species with grayish brown indistinct borders, almost wide.

Material examined

Sindh Khairpur Mir's several specimens 5.ix.2018 
Grammodes stolida (Fabricius, 1775) Diagnosis

Forewing having black brownish patches at its basal half, costal and sub-costal region possess streaks. Outer parts are half yellow in color, biconcave, narrowed at below with brownish bands. Genitalia thread shaped, usually without distinct margins

\section{Material examined}

Pakistan several specimens Sindh Province Khairpur Mir's

\section{5.xi.2018}

\section{Graphania pagaia (Hudson, 1909)}

Diagnosis. Head and thorax cream color Fore wings longer than the abdominal segments.

Hind wings grey- brown, outer part darker. Genitalia asymmetrical, broad and erect processes relatively long and coiled.

\section{Material examined}

Sindh Khairpur Mir's several specimens 15.x. 2018

\section{Helicoverpa armigera (Hübner, 1808) Diagnosis}

Body vary in colour and size. Fore-Wing yellow to orange in colour of females and green to grey of male species, having darker bands on its distal region. Antennae is filiform. Hind wing pale yellowish having brown narrow bands on its outer edges. The genitalia, robust but narrow and apically hooked.

\section{Material examined}

Sindh Several specimens Khairpur Mir's 17.x. 2018

\section{Heliothis armigera (Hübner, 1808) \\ Diagnosis}

The body usually off white or somehow creamy in coloration. Fore-wings with two distinct minute dots. Hind wings creamy at its half part and half lunar in shape darker. Genitalia broad, nearly symmetrical short and membranous.

\section{Material examined}

Pakistan several specimens Sindh Province Khairpur Mir's

09.iii. 2018

\section{Dipaustica epiastra (Meyrick, 1911) Diagnosis}

Head prominent with clear margins. Fore wings clay yellowish in color, with several blackish dots surrounded to the margins. Hind wings completely clay yellowish in color. Genitalia narrow, with rounded margins.

Material examined. Pakistan several specimens Sindh Province Khairpur Mir's 12.iv. 2018

\section{Dysgonia algira Linnaeus, 1767}

Diagnosis

Body brownish in color, Head concave shaped. Fore wing brown with minute white spot. Hind wings greyish in color. Genitalia of this species is broader as compared to the other species occurring in Noctuidae. Wide at the base and slightly tapers to apex with hairy projection.

\section{Material examined}

Several specimens Sindh Khairpur Mir's 7.vi. 2018

\section{Discussion}

Moths belongs to family Noctuidae are phytophagous and considered as distinctive and prime group of insects in order Lepidoptera. Their larvae consume variety of crops and thus causing damage to agriculture. Butterflies and moths are belonging to order Lepidoptera are mostly plant eating and severe pests of agriculture crops [1], they constitute nearly 155,000 species described from various regions [2, 3].

Butterflies and moths remain phytophagous at their larval stage and rely on nectar on adult stage. They are considered as different group of ecosystems working as plant eaters, fertilizers and provide damage to agriculture [4]. Roughly there are 6000 butterflies and moths noted for financial importance and about quarter of these have a place with Noctuoidea [5].

Extensive surveys were carried out to collect Noctuidae fauna of district Khairpur Mir's. A total of 221 specimens were captured and were identified into 11 genera and 15 species of Noctuidae i-e: Mythimna unipuncta, (Haworth, 1809), Mythimna 
impura (Hübner, 1808), Heliothis adaucta Butler, 1878, Heliothis peltigera (Denis \& Schiffermüller, 1775), Heliothis armigera (Hübner, 1808), Agrotis ipsilon (Hufnagel, 1766), Agrotis exclamationis (Linnaeus, 1758), Meterana pansicolor (Howes, 1912), Meterana alcyone (Hudson, 1898), Spodoptera litura (Fabricius, 1775), Grammodes stolida (Fabricius, 1775), Graphania pagaia (Hudson, 1909), Helicoverpa armigera (Hübner, 1808), Dipaustica epiastra (Meyrick, 1911) and Dysgonia algira, Linnaeus in 1767. A checklist of 20 species and subspecies of the genus Yigoga Nye, 1975 (Lepidoptera: Noctuidae) together with the Iranian records in various territories of Iran. The first blend, reference of the first depiction and the type region of every species were exhibited [20]. Lepidopteran species were explored. To gather specimens, a net and light traps were utilized. An aggregate of 109 species having a place with 17 families of the Lepidoptera were recognized. The family Geometridae was spoken to by the most elevated number of species (20), trailed by Noctuidae (19), Lycaenidae (12) and Nymphalidae (12). This was the primary study to decide the Lepidoptera fauna of Duzce [21]. Recent studies on genus Thysanoplusia Fabricius stated that it is a polyphagous pest of vegetables, foods, legumes, fodder, fruits, ornamental plants, and cotton crops belonging to the genus Thysanoplusia Fabricius of the subfamily Plusiinae. Samples were taken from various locations throughout the Bahawalpur district. Comprehensive and comparative surveys on taxonomic account of species of the genus Thysanoplusia Fabricius were conducted in 2017-18 for the purpose of collection, and one species, Thysanoplusia orichalcea (Fabricius), was identified for the first time from Pakistan. For identification and classification, morphological characters such as the vertex, frons, labial palpi, antennae, compound eyes, ocelli, proboscis, wing venation, and male and female genital characteristics were used. There are also dichotomous keys and photographs. There is not much research on taxonomic studies of the Plusiinae subfamily in Pakistan. To fill this void, the current proposal was created to investigate the diversity of Noctuid moths in Pakistan, with very promising results [22].

Additionally, species descriptions along with photographs are given for identifying species of moths. This study proves to be first step towards to Noctuidae biodiversity of Khairpur district for first time.

\section{Conclusion}

Present study concludes that Noctuid moths are pest of various agricultural crops, forests, fruits and vegetables. In addition to this they are the diverse group among the order Lepidoptera so their proper diagnosis should be conducted in order to know their systematic importance.

\section{Future directions}

The basic aim of this study was to give detailed description of noctuid species of Khairpur district. Following parameters are still waiting for future scientists:

1. Ecology of Noctuidae species should be carried out in order to find the pest status of these species.

2. Molecular approaches should be carried out to find difference amongst subfamilies up to species level.

3. Scanning Electron Microscopy should be done to see fine structures of Noctuidae.

4. Biology, life cycle of Noctuidae should be carried out in detail.

\section{Authors' contributions}

Conceived and designed the experiments: $\mathrm{P}$ Soomro, WA Panhwar \& AM Shaikh, Performed the experiments: P Soomro \& AM Shaikh, Analyzed the data: KH Memon, JA Ujjan \& SA Ujjan, Contributed materials/ analysis/ tools: ZN Memon, $\mathrm{M}$ Ruk \& S Mangi, Wrote the paper: P Soomro \& WA Panhwar.

\section{References}

1. Scoble MJ (1992). The Lepidoptera. Form, function and diversity. Oxford University Press. 
2. Pogue MG (2009). Biodiversity of Lepidoptera. Insect Biodiver Sci and Soc 325-355.

3. Van Nieukerken EJ, Kaila L, Kitching IJ, Kristensen NP, Lees DJ, Minet J \& Wahlberg N (2011). Order Lepidoptera Linnaeus, 1758. Zootax 3148: 212-221.

4. Cho S, Mitchell A, Mitter C, Regier J, Matthews M \& Robertson RON (2008).

Molecular phylogenetics of heliothine moths (Lepidoptera: Noctuidae: Heliothinae), with comments on the evolution of host range and pest status. Syst Entomol 33(4): 581-594.

5. Regier, JC, Zwick A, Cummings MP, Kawahara AY, Cho S, Weller S \& Davis DR (2009). Toward reconstructing the evolution of advanced moths and butterflies (Lepidoptera: Ditrysia): an initial molecular study. BMC Evolut Biol 9(1): 280.

6. Zhang, BC. (1994). Index of Economically Important Lepidoptera. Wallingford: $C A B$ Interna pp. 599.

7. Mitchell A, Mitter C \& Regier JC. (2006). Systematics and evolution of the cutworm moths (Lepidoptera: Noctuidae): evidence from two protein-coding nuclear genes. Systemat Entom 31(1):21-46.

8. Kitching IJ. (1984). The use of larval chaetotaxy in butterfly systematics, with special reference to the Danaini (Lepidoptera: Nymphalidae). Systemat Entom 9(1): 49-61.

9. Aslam M. (2013). Checklist of moth fauna of Peshawar, Pakistan. Arthrop 2(4): 237241.

10. Banziger H. (1982). Fruit-piercing moths (Lep.,Noctuidae) in Thailand: a general survey and some new perspectives. Mitteilungen Entomolog Gesell 55(3/4): 213-240.

11. Bethune-Baker GT (1914). XI. Notes on the Taxonomic value of Genital Armature in Lepidoptera. Ecol Entom 62(2): 314338.

12. Heinrich C (1921). Some Lepidoptera likely to be confused with the pink bollworm. J Agri Res 20(11): 807-836.
13. Eyer JR (1926). The morphological significance of the juxta in the male genitalia of Lepidoptera. Bul Broo Ent Soc 21: 32-37.

14. Sivasankaran K, Thangadurai TB, \& Ignacimuthu S (2011). Studies on external genitalial morphology of subfamily Catocalinae (Lepidoptera: Noctuidae). $J$ Res Biol 8: 631-642.

15. Fibiger M., \& Lafontaine JD (2005). A review of the higher classification of the Noctuoidea (Lepidoptera) with special reference to the Holarctic fauna. Delta-Dr. und Verlag Peks.

16. Beehag G, Kaapro J \& Manners A (2016). Pest Management of Turfgrass for Sport and Recreation. CSIRO Publishing.

17. Kainat M, Panhwar WA., Mehmood S A \& Cengiz FC (2017). Incidence and distribution of diamondback moth (Plutella xylostella) from district Mansehra. J Entom \& Zool Stud 5(1): 184-185.

18. Carrière Y, Ellers-Kirk C, Patin A.L, Sims MA, Meyer S, Liu YB \& Tabashnik BE (2001). Overwintering cost associated with resistance to transgenic cotton in the pink bollworm (Lepidoptera: Gelechiidae). $J$ Econo Entom 94(4): 935-941.

19. Lei Y, Zhu X, Xie W, Wu Q, Wang S, Guo Z \& Zhang Y (2014). Midgut transcriptome response to a Cry toxin in the diamondback moth, Plutella xylostella (Lepidoptera: Plutellidae). Gene 533(1): 180-187.

20. Kazemi E \& Shirvani A (2012). A checklist of Caradrina Ochsenheimer, 1816 (Lepidoptera, Noctuidae, Xyleninae) of Iran. Nat Monteneg Podagr 11(3): 443-453.

21. Akbulut S, Yüksel B \& Keten A (2003). The Lepidoptera (Insecta) fauna of Düzce province, Turkey. Turk J Zool 27(4): 257268.

22. Sajjad M, Sarwar ZM, Hussain SI, Zaka SM, Saeed Q, Bodlah I \& Khan KA (2020). First record and taxonomic description of the genus Thysanoplusia (Fabricius) (Lepidoptera: Noctuidae: Plusiinae) from Pakistan. Saudi J of Biol Sci 27(5): 13751379. 